\title{
Marketing of Women Shgs Products (with Special Reference to Chennai City)
}

\author{
K.Prabhakar Rajkumar, D.Bhuvana
}

\begin{abstract}
Empowerment concerns folks - both women as well as men - taking control over their everyday lives: becoming conscious of their personal situation and setting, preparing their personal plans, creating space on their own, gaining skill-sets, building confidence, handling concerns, as well as cultivating self-reliance. The stamina of the link is the strength of its own weakest link. In society, women are actually the weakest hyperlinks, to ensure that they must be actually enhanced for reinforcing the culture overall which is possible only through enabling all of them. Nehru said, "Women must be uplifted for the upliftment of the nation, for if a woman is boosted, society, as well as nation, are boosted". The Women Self Aid Group participants are coming from rural areas and also do not possess much direct exposure to metropolitan history as well as a lot of all of them battle to manage the urban area ambiance. Much of the members also hesitate to approach financial institutions and also training institutions to produce more powerful their economic along with mental stamina. The family members' instances are actually also certainly not enabling the members to end up being extra dynamic as well as they are straining to handle family members and also an organisation in the right instructions. When the members furnish themselves along with overall advertising and marketing tactics with the adoption of SWOT analysis at that point just they may survive in the Chennai market.
\end{abstract}

Keyword: society, SWOT.

\section{INTRODCTION}

Women authorization participates in an essential function in the progression of adored ones, neighborhood, nation as well as the world as a whole. To have an understanding of the health condition 'women empowerment', an understanding of condition permission is really vital. Words 'em powerment' means 'enabling'. Depending On to International Encyclopaedia (1999), power recommends having the capability and additionally the approaches to steer one's life towards yearned for social, political as well as financial intendeds or even standing. For that reason, women empowerment proposes delivering the capability as well as likewise suggests to drive women's way of living in the direction of preferred objectives.

Women Empowerment

Consent of women is in fact a pushing need of the time. Nonetheless, it is really the very least understand. It is really as a result quite important to determine permission for the benefit of all companions: Authorization issues folks - both women and people - taking monitoring over their lives: becoming conscious of their exact own instance in addition

Revised Manuscript Received on November 05, 2019.

Dr.K.Prabhakar Rajkumar, Associate Professor, Department of Commerce, Periyar University, Salem -11, Tamil Nadu, India.

Dr. D.Bhuvana, Assistant Professor, Department of Commerce, St. Joseph's College of Arts and Science, Hosur, Tamil Nadu, India.

Email : kudalkprk6@yahoo.co.in to position, developing their own plans, producing room for themselves, getting skill-sets, designing positive self-image, taking care of worries, and also setting up self-direction. It is actually undoubtedly not merely a social and also political procedure, yet a private one also - and it is really certainly not merely a procedure yet an end result as well. Outsiders may surely not enable women: merely women can easily allow themselves, to opt for or maybe to speak up by themselves part. Having said that, business, NGOs along with Government firms, might assist procedures that enhance women's confidence, generate their autonomy, as well as help them develop their extremely personal routines.

\section{Women SHG physical body in India:}

The idea of Women Personal Assistance Teams was actually welcomed due to the Authorities of India as it s primary aim to eliminate challenge. The condition Women 'Self-Help Groups' is typically made use of in India to describe non listed uncompromising organization of unsatisfactory folks of 10 to twenty, coming from the exact same socio money-saving staff, including mostly in sparing along with credit rating duties. In 1976, Prof. Mohammed Yunus of Bangladesh began women's teams in Bangladesh as well as developed thrift and cost discounts amongst the poorest. Currently it has developed into a bank referred to as Bangladesh Gramin Banks.

\section{Tamil Nadu and additionally Women SHGs:}

Tamil Nadu is actually just among the prevalent states promoting development of Women SHGs next to Andhra Pradesh and also Kerala. The NGOs in addition to Banking companies are really delivering credit report centers to Women SHGs' participants. Yet the features of NGOs are much bigger than financial institutions in ensuring credit score ranking to bad folks, given that the banking companies are in fact certainly not stretching this provider to the bad. Lots of explores comparative that the Micro Money is actually simply some of the guitars to remove poverty in backwoods. Nonetheless, in back ailments as well as also areas dealt with help coming from NGOs were actually lacking. Nonetheless National Banks for Agriculture as well as additionally Rural Development (NABARD) is really discovering to consist of Women SHGs. The advertising tries specifically executed through NABARD in the final 2 years have actually led to a considerable development of programme past expectation.

Women Individual Support Crews in Chennai Urban Place: 
In Chennai metropolis an optimum of 27,717 Women SHGs were situated in 10 Zones, like Tondiarpet, Basin bridge, Pulianthope, Ayanavaram, Kilpauk, Ice home, Nungambakkam, kodampakkam, saidapet, as well as additionally Adyar. Chennai is merely some of the Metropolitan Districts assuring accumulation of Women SHGs. In Chennai metropolitan area, Women Personal Assistance Teams are in fact little teams of poor and also they support each other to resolve their problems, when the participants of Women SHG s skin layer similar problems. The attendees of the Women SHG are really required to reduce a routine manner. The periodicity and quantum of discounts are determined by team on their own. These economic discounts by the participants need to be in fact pinpointed as a monetary discounts thing offering lasting monetary necessities. Apart from the normal needed expense savings, the Women SHG individuals are actually urged to spare the added volume as special anywhere possible. These expense financial savings are in fact placed in their savings Bank profile, which are actually presumed while getting more significant car loan quantity arising from the bank. This is actually the typical fund for the Women SHGs. The Women SHG offers little finances to its own participants coming from its very own traditional fund. After 6 months, if the Women SHG delights the banks, according to the inspection checklist for ranking high quality, banking firm may give finances to the Women SHG. In the Chennai city location women SHGs may conveniently conserve percentage in banks. The crew participants conserve in the financial account. They notice 6 months for all numerous other tasks as well as the banking company must offer home mortgage to the teams. Very first time the financial institution responds loan and likewise the team members divide to offering volume amongst each in addition to pay the funding regularly. Financial together with a larger variety of folks allows financial institutions to obtain a good credibility and reputation. The banking company must stick to the team activity successfully. Along with the numerous firm duties they have actually figured out specific practical duties as fit for women SHGs in this particular specific area. They are Artificial Jewelry introduce, Jute, Cotton sarees, Needlework job, Cashew almond investment, Cleansing soap, Cleaning Surface, Artificial Vegetation, Clay-based Dollies introduce as well as likewise Hemp, Leather-made goods, Art work, Seashell products, Terra-cotta, Readymade garments sales and also bring in and additionally selling, Oil, Dry fruit products, Bake shop, Quick meals items, Pastry shop Liquid, Sanitary pad, Tamarind operation, Vermi compost, Ceramic, Flower increasing, Hardwood Toys, Wax, Pooja products, Tamil Nadu insert, Block series, Block making, Hand jaggery, Palmcandy, Jelly Pickles and so on. They are actually supplying even more advertising possibilities by means of Political Satisfying, accomplishing display and so on. Some team members are actually essentially illuminated as well as also these individuals create advertising and marketing chance for individuals as well as likewise teams.

\section{Marketing Problems of Women SHGs Products in Chennai Urban Location:}

Marketing and advertising is actually another area which typically finds out the income levels of your business owner due to the ups and also downs of the requirement. Much of the Women SHGs members experienced a quantity of concerns concerning the advertising and marketing of their service or products in Chennai area. According to the scientist's mass study in Chennai city region a great deal of the participants presented that the issues which they experienced are really 1 . Ineptness to put up with the competitions originating from modern items. 2. No distinct market or acquire Women SHGs products. 3. No appealing packing in addition to necessary advertising campaign, 4. Individuals' perception on Women SHGs items, 5. Competitions coming from the a lot less pricey items, 6 . Postpone in obtaining settlements coming from the customers, 7. Reduced need as a result of access of alternative things, 8. Added transportation expenses, 9. Scarcity of particulars concerning markets and 10 . Shortcoming to publicize their items.

Touring arising from one place to one more is in fact an issue to Women SHGs attendees in Chennai place. Representatives bug much of the women individuals, as women are believed to be actually much a lot less able to look at all advertising and marketing proceedings. The prior chats reveals that advertising of Women SHGs individuals are actually far at the back of as a result of lack of economical help, member of the family and additionally area help unawareness of the options, absence of motivation, shyness, restrictions, disposition for the typical occupations and so on. The Women SHGs attendees must strengthen the first class using different approaches as well as obtain much better skills to face competition. Person contact have to be in fact created with a great deal of individuals for using the chances in the industry and also to prevent problem in discharges in addition to enhance the advertising of their items.

\section{ANALYSIS AS WELL AS USEFULNESS OF SWOT ANALYSIS}

A SWOT research gauges a provider system, a recommendation or idea; a BLOODSUCKER evaluation examines a market. A SWOT customer review is actually a private examination of reports which is managed by the SWOT style right into a logical order that aids understanding, discussion, discussion and also choice -making. The 4 measurements are a valuable development of a basic pair of relocating guidelines of advantages as well as downsides. SWOT evaluation can be made use of for all kind of decision-making, as well as additionally the SWOT design template allows useful reasoning, as opposed to depending on recurring or even inherent responses. In Women SHGs involved their, sturdiness examine interior attributes that are actually practical to the Women SHGs to achieve their goals, weak spots assess inner attributes that are in fact harmful to the Women SHGs in securing their reasons. Opportunities are outside elements that support the Women SHGs to achieve their targets as well as hazards are evaluated due to the outdoor components that are actually harming to the Women SHGs in accomplishing their goals. After determining the SWOT's, i.d. of the factors as well as also their link assists to clear the measures called for to achieve completion objectives. 
With revealing incredibly clear purposes in addition to realizing inner as well as exterior factors that are actually either useful or not, a simple and additionally essential SWOT evaluation is actually an useful source which may be combined in to a Women SHGs tactical preparing model.

\section{SWOT Examination for Women Personal Support Staffs in General:}

\section{Durabilities:}

Aid in producing affordable self-direction of the members through satisfying intake as well as also making credit scores as and also when they happen. Shield versus the participants originating from the profiteering of the non-institutional debt record resources. Support banks in recuperation of credit report by means of motivating participants for on schedule repayment of financings in addition to acquire gratitude and also interest arising from the financial institutions. Help the members to accomplish the procedures and additionally records demanded to receive credit score file banking company. Enhancing of women's adored one setup within a co-dependent alliance alongside their hubbies in looking for self-reliance and additionally liberty. Visits at frequent durations claim routine or perhaps biweekly to build a challenging bond in between the participants there certainly by means of supplying a possibility to members to share effortlessly their sights, presumptions and also pointers for boosting the performance of the team. Builds team task, management premiums and also furthermore reinforces decision-making abilities. Shows pre-owned practices and also improvements the amount of conserving amongst the participants. Assists to set up positive self-image as well as makes it possible for the members to meet any kind of type of banking business official without anxiety in addition to shyness.

In particular occasions of decided on Women SHGs the incomes stemming from your service is really certainly not properly put in additionally in the tool as well as likewise the funds are actually drawn away for numerous other personal as well as residential objectives like relationship, progression of home and so on. They deal with issues of marketing and advertising because of poor purchases as well as insufficient purchases discount actions. There is actually vacancy of turning of leadership stance amongst Women SHGs participants. Persistence due to the financial institution divisions for locking out whole entire cash loan conserving of Women SHGs along with all of all of them along with also requiring collateral security for growth funds to Women SHGs. Not able to channelise the revenue and profit as a result of inadequate training resources to the participants of Women SHGs.

\section{Opportunities:}

To nurture group parts, generating management premium to discover their potentiality and also self-belief. To advertise personal- employment jobs as well as a result boosting their practical positions. To prompt, involvement in Socio financial progress programs like Effectiveness, Healthcare, Real estate, Hygiene etc. for the overall permission of country women.

\section{Hazards:}

Financial institutions carry out dismiss Women SHGs seriously while providing monetary as well as various other helps. Higher competitors from various other key vendors due to lack of affiliation along with advertising and marketing firms.

\section{Declaration of the Trouble}

Women Personal Self-help Group (SHG) participates in necessary duty in country and also urban places through making as well as additionally offering the products. Advertising and also industrying the products assisted help make by Women SHG's is actually a notable and likewise difficult one as the items must be supplied with the non-urban marketing and advertising concept to the metropolitan customers. Advertising and marketing these things in the metropolitan regions is actually far more daunting. The Women SHG are heading to must stress on the high quality as well as additionally sensible rate to enhance the sales. Therefore Women SHGs will undoubtedly require to have a look at the strategies as well as additionally indicates of supplying services or product that delight the criteria of urban individual and progress appropriate communication technique and additionally market advertising. This research study measures as well as likewise analyze what sort of SWOT procedure is better to eliminate the marketing and advertising concerns in Chennai and also just exactly how the Women SHGs have to do several functions of the provider which the business by themselves need to deal with along with the modern-day approach is in fact one component and also one more parts is that advancement of items through Women SHGs is really a stressful one but industrying these items in urban areas like Chennai area is in fact a sophisticated one. The best objective advising Women SHGs is in fact revenue producing via a company and additionally to extend a team business.

\section{REASONS OF THE INVESTIGATION STUDY}

1. To evaluate the build-up and functions of Women Personal Help Groups in

Chennai Metropolitan area.

2. To spot the general business efficiency of Women SHGs in Chennai

Urban area.

3. To learn the purchaser attitude and additionally tastes in the direction of the Women Personal

Assistance Team items and also

4. To examine the variables affecting the investment of Women SHGs' items.

The performance of SWOT on total Influence of Women Personal Support Group in Chennai City can be examined with reference to many variables like Personal Improvement and Team Remodeling with SWOT evaluation on total advancements in personal, in group and also in market. The SWOT and also Impact of women Self Assistance Groups have been actually determined by means of percent evaluation, t-test, Anova, Cluster. Lastly connection and also regression review have been brought in taking SWOT as well as Impact of Women Self Help Teams. 
This research is completely based upon main data and analysis thereof. The evaluation is actually done under Five groups such as 1. Category of teams according to their adjustment of SWOT 2.

Evaluation of SWOT elements among the three regions in the Chennai Metropolitan area. 3. Organization between SWOT factors and elements of advertising and marketing 4. Affiliation in between Internal and Exterior factors of SWOT and also pinpoint its prevalent aspects and 5. Consumer evaluation of Women Self Help Group products in different dimension.

The viewpoint conveyed by member participants on a practical series of advertising and marketing and also SWOT issues are listed here, using favorable and also negative claims showing the insurance coverage, magnitude plus all qualities of SWOT in the urban market like Chennai urban area. The essential factors are given below.

Table -1 Relation between Publicity for Increasing the Sale of Product and SWOT Factors

\begin{tabular}{|l|l|l|l|r|r|}
\hline \multirow{2}{*}{ Factors } & Sources & N & Mean & $\begin{array}{c}\text { Std. } \\
\text { Deviation }\end{array}$ & $\begin{array}{c}\text { Std. Error } \\
\text { Mean }\end{array}$ \\
\hline \multirow{2}{*}{ Impact } & Yes & 141 & 4.2845 & .59387 & .05001 \\
\cline { 2 - 6 } & No & 241 & 4.0404 & .66575 & .04288 \\
\hline \multirow{2}{*}{ Strength } & Yes & 141 & 4.6865 & .42812 & .03605 \\
\cline { 2 - 6 } & No & 241 & 4.5878 & .53999 & .03478 \\
\hline \multirow{2}{*}{ Weakness } & Yes & 141 & 3.3558 & .61624 & .05190 \\
\cline { 2 - 6 } & No & 241 & 3.4090 & .53316 & .03434 \\
\hline \multirow{2}{*}{ Opportunity } & Yes & 141 & 4.7362 & .40414 & .03403 \\
\cline { 2 - 6 } & No & 241 & 4.6680 & .52672 & .03393 \\
\hline \multirow{2}{*}{ Threats } & Yes & 141 & 3.6369 & .77010 & .06485 \\
\cline { 2 - 6 } & No & 240 & 3.6783 & .60406 & .03899 \\
\hline
\end{tabular}

The impact of attention to increase sale of SHG items to improve your service is actually sizable over Personal enlargement, Team improvement, toughness, alternative, weak spot and likewise dangers. The use of individual t-test brad assistances to satisfy the research study. It is really found that the mean value of Influence on Women Personal Support Teams alongside improved purchases (way= $4.2845)$, strength (way $=4.6865)$, weakness (procedure $=$ $3.4090)$, choice (way $=4.7362$ ) and also dangers (strategy= 3.6783 ) are really specifically figured out with the mean value of teams without rearing the item purchases. The substantial difference between mean values are actually matched up with t-statistic as well as additionally given through.
Table-2: Relation betwreen Publicity for Increasing the Sale of Product and STrOI Factors

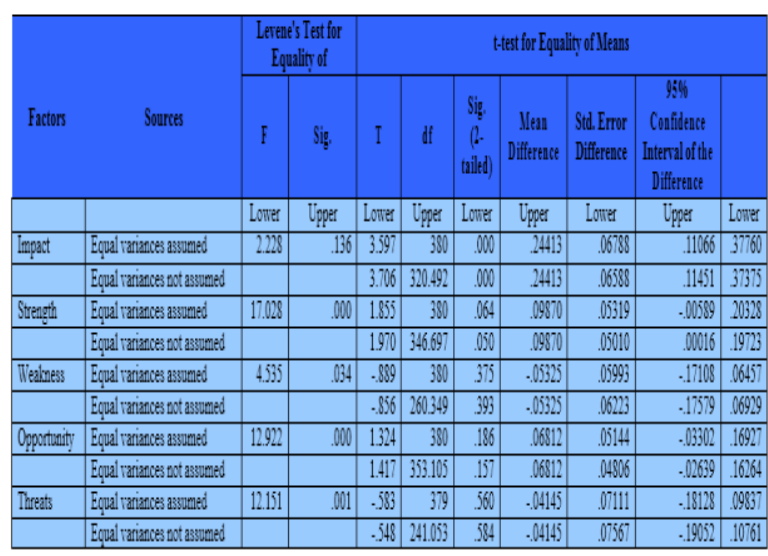

Coming from the above table it lies that t-value of Impact on Women Individual Aid Teams $t=3.597, p=0.000$, Strong suit $\mathrm{t}=1.855, \mathrm{p}=0.064$, Powerlessness $\mathrm{t}=-0.889, \mathrm{p}=0.375$, odds $\mathrm{t}=1.324, \mathrm{p}=0.186$, threats $\mathrm{t}=-583, \mathrm{p}=0.560$ are actually statistically notable at $5 \%$ level. This proposes the method prudent comparison in between pair of teams along with their buddy. It lies that the Women Self Assistance Team participants have the capability to improve the item investments and additionally it is actually firmly acknowledged through their positive Impact on Women Individual Assistance Groups activities. It is in fact set up that the Women Self Aid Team members without promo to their things experienced 4.2845 , durability 4.6865 , weakness of 3.4090 possibility 4.7362 along with dangers of 3.6783 in addition to it offers that to raise the thing acquisitions with focus they minimize their powerlessness as well as additionally risks in their company tasks as well as the influence is positive.

Customers' Review of SWOT on High Quality Product of Women Personal Assist Teams

In the last and last stage the scientist would like to assess the client perspective in the helpful and also damaging elements on the Women Personal Assistance Teams' product. Below, the researcher desires to hook up the relevance given with customers to first class portion of the Women Personal Support Groups' item along with overall SWOT aspects of Women Personal Support Groups. Furthermore the analyst furthermore wishes to examine the various sizes of Women Self Aid Teams' products due to the clients.

Ho. There is actually no relation in between the SWOT elements and also clients point of view on high quality of things produce by means of Women SHGs in the 3 Areas.

Table - 3 Relation between the SWOT Factors and Quality of Products Manufacture by Women SHGs in the Three Zones. 


\begin{tabular}{|c|c|c|c|c|c|c|c|c|c|}
\hline \multirow{2}{*}{ Factors } & \multirow{2}{*}{ Sources } & \multirow{2}{*}{\begin{tabular}{|c|}
$X$ \\
Lowrer \\
Bound
\end{tabular}} & \multirow{2}{*}{$\begin{array}{l}\text { Mean } \\
\text { Upper } \\
\text { Bound }\end{array}$} & \multirow{2}{*}{$\begin{array}{c}\text { Std. } \\
\text { Deriation } \\
\text { Lorrer } \\
\text { Bound }\end{array}$} & \multirow{2}{*}{$\begin{array}{l}\text { Std } \\
\text { Error } \\
\text { Upper } \\
\text { Bound }\end{array}$} & \multicolumn{2}{|c|}{$\begin{array}{l}\text { 95\% Confidence } \\
\text { interval for Mean }\end{array}$} & \multirow{2}{*}{\begin{tabular}{|c|} 
Minimum \\
Lowrer \\
Bound \\
\end{tabular}} & \multirow{2}{*}{\begin{tabular}{|c|} 
Maximum \\
lpper \\
Bound \\
\end{tabular}} \\
\hline & & & & & & $\begin{array}{l}\text { Lowrer } \\
\text { Bound }\end{array}$ & $\begin{array}{l}\text { Tpper } \\
\text { Bound }\end{array}$ & & \\
\hline \multirow[t]{4}{*}{ Strenghth } & North & 86 & 4.4876 & .52883 & 05703 & 4.3742 & 4.6010 & 3.00 & 5.00 \\
\hline & Central & 94 & 4.7929 & .41656 & .04296 & 4.7076 & 4.8782 & 3.27 & 5.00 \\
\hline & South & 203 & 4.6010 & .51029 & 03582 & 4.5304 & 4.6716 & 2.87 & 5.00 \\
\hline & \begin{tabular}{|l|} 
Totala \\
\end{tabular} & 383 & 4.6226 & .50364 & .02574 & 4.5720 & 4.7322 & 2.87 & 5.00 \\
\hline \multirow[t]{4}{*}{ Wealness } & North & 86 & 3.1153 & 38456 & 04147 & 3.0328 & 3.1977 & 2.25 & 4.08 \\
\hline & Central & 94 & 3.4282 & .37019 & 03818 & 3.3524 & 3.5040 & 2.67 & 4.50 \\
\hline & South & 203 & 3.4906 & .66010 & 04633 & 3.3992 & 3.5819 & 1075 & 4.83 \\
\hline & \begin{tabular}{|l|} 
Totala \\
\end{tabular} & 383 & 33910 & .56516 & 02888 & 3.3342 & 3.478 & 1.75 & 4.83 \\
\hline \multirow[t]{4}{*}{ Opportunity } & North & 86 & 4.474 & .57069 & 066154 & 4.3521 & 45968 & 320 & 5.00 \\
\hline & Central & 94 & 4.8287 & .38005 & .03920 & 4.7509 & 4.9066 & 3.40 & 5.00 \\
\hline & Sooth & 203 & 4.7212 & .46084 & .03234 & 4.6574 & 4.7850 & 3.00 & 5.00 \\
\hline & \begin{tabular}{|l|} 
Total \\
\end{tabular} & 383 & 4.6922 & .45543 & .22880 & 4.6434 & 4.7409 & 3.00 & 5.00 \\
\hline \multirow[t]{4}{*}{ Threats } & North & 86 & 3.3682 & .64866 & 07036 & 3.2283 & 3.0081 & 2.00 & 5.00 \\
\hline & Central & 94 & 3.5266 & .4605 & .04601 & 3.4552 & 3.6180 & 2.10 & 4.80 \\
\hline & South & 203 & 3.5512 & .70475 & 04946 & 3.7537 & 3.9488 & 2.10 & 5.00 \\
\hline & Iotalal & 383 & 3.6639 & .66996 & .03423 & 3.5966 & 3.7312 & 2.00 & 5.00 \\
\hline
\end{tabular}

Table -4 Relation between the SWOT Factors and Quality of Products Manufacture by Women SHGs in the Three Zones.

\begin{tabular}{|c|l|r|r|r|c|c|}
\hline \multirow{4}{*}{ Strength } & $\begin{array}{c}\text { Sum of } \\
\text { Squares }\end{array}$ & df & $\begin{array}{c}\text { Mean } \\
\text { Square }\end{array}$ & F & Sig. \\
\hline & Between Groups & 4.389 & 2 & 2.194 & 9.014 & .000 \\
\cline { 2 - 8 } & Within Groups & 92.509 & 380 & .243 & & \\
\cline { 2 - 8 } & Total & 96.897 & 382 & & & \\
\hline \multirow{4}{*}{ Weakness } & Between Groups & 8.680 & 2 & 4.340 & 14.553 & .000 \\
\cline { 2 - 8 } & Within Groups & 113.331 & 380 & .298 & & \\
\cline { 2 - 8 } & Total & 122.012 & 382 & & & \\
\hline \multirow{3}{*}{ Thportunity } & Between Groups & 6.001 & 2 & 3.001 & 13.572 & .000 \\
\cline { 2 - 8 } & Within Groups & 84.015 & 380 & .221 & & \\
\cline { 2 - 8 } & Total & 90.017 & 382 & & & \\
\hline & Between Groups & 16.327 & 2 & 8.163 & 2.067 & .000 \\
\cline { 2 - 8 } & Within Groups & 154.175 & 379 & .407 & & \\
\cline { 2 - 8 } & Total & 170.501 & 381 & & & \\
\hline
\end{tabular}

Coming from the above table it could be found that Advantage, Weak Point, Option as well as likewise Threats are actually significant relative to items made in North, Central in addition to South Zones. These causes advise practical contrast and it is located that the teams making product in major zone recognized the maximum durability $($ way $=4.7929)$ as well as the south area protected the greatest powerlessness (procedure $=3.4906$ ) as well as likewise core region has gotten maximum option (technique $=4.8287$ ) as well as additionally the south location realized optimal dangers (method=3.8512).

As a result, the researcher ended that the theory is denied along with all the 3 areas, in gratitude of premium products generated by Women SHGs are actually related to SWOT think about Chennai Area.
Table - 5 Relation between the Customers' Evaluation of the Product, Place, Pricing, Promotion, People and Process

\begin{tabular}{|c|c|c|c|c|c|c|c|c|c|}
\hline \multirow{2}{*}{ Factors } & \multirow{2}{*}{ Sources } & \multirow{2}{*}{\begin{tabular}{|c|}
$\mathrm{X}$ \\
Lowrer \\
Bound
\end{tabular}} & \multirow{2}{*}{$\begin{array}{l}\text { Mean } \\
\text { Upper } \\
\text { Bound }\end{array}$} & \multirow{2}{*}{$\begin{array}{l}\text { Std. } \\
\text { Deriation } \\
\text { Lowrer } \\
\text { Bound }\end{array}$} & \multirow{2}{*}{$\begin{array}{l}\text { Std } \\
\text { Error } \\
\text { Upper } \\
\text { Bound }\end{array}$} & \multicolumn{2}{|c|}{$\begin{array}{l}95 \% \text { Confidence } \\
\text { interval for Mean }\end{array}$} & \multirow{2}{*}{$\begin{array}{l}\text { Minimum } \\
\text { Lower } \\
\text { Bound }\end{array}$} & \multirow{2}{*}{$\begin{array}{c}\text { Maximum } \\
\text { Upper } \\
\text { Bound }\end{array}$} \\
\hline & & & & & & $\begin{array}{l}\text { Lowrer } \\
\text { Bound }\end{array}$ & $\begin{array}{l}\text { Upper } \\
\text { Bound }\end{array}$ & & \\
\hline \multirow{4}{*}{ Procuct } & North & 71 & 3.2901 & .57449 & .06818 & 3.1542 & 3.4261 & 2.40 & 5.00 \\
\hline & Central & 79 & 3.3899 & 34626 & .03896 & 3.3123 & 3.4674 & 2.60 & 4.40 \\
\hline & South & 163 & 32822 & 31874 & .02497 & 3.2328 & 33315 & 2.40 & 4.60 \\
\hline & Total & 313 & 3.3112 & 39860 & .02253 & 3.2669 & 3.3555 & 2.40 & 5.00 \\
\hline \multirow{4}{*}{ Place } & North & 71 & 4.1901 & .58166 & .06903 & 4.0525 & 4.3278 & 3.00 & 5.00 \\
\hline & Central & 79 & 3.5443 & 35975 & .04048 & 3.4637 & 3.6249 & 3.00 & 4.50 \\
\hline & South & 163 & 3.4448 & .29400 & .02303 & 3.3993 & 3.4903 & 2.50 & 5.00 \\
\hline & Total & 313 & 3.6390 & 49421 & .02793 & 3.5840 & 3.6939 & 2.50 & 5.00 \\
\hline \multirow{4}{*}{ Pricing } & North & 71 & 3.7203 & .44685 & .05303 & 3.6146 & 3.8261 & 2.86 & 5.00 \\
\hline & Central & 79 & 3.8897 & .27541 & .03099 & 3.8280 & 3.9514 & 3.14 & 4.57 \\
\hline & South & 163 & 3.6757 & 30245 & .02369 & 3.6289 & 3.7225 & 2.86 & 5.00 \\
\hline & Total & 313 & 3.7398 & 34522 & .01951 & 3.7015 & 3.7782 & 2.86 & 5.00 \\
\hline \multirow{4}{*}{ Promotion } & North & 71 & 4.3732 & .55881 & .06632 & 4.2410 & 4.5055 & 200 & 5.00 \\
\hline & Central & 79 & 4.6456 & 40153 & .04518 & 4.5556 & 4.7355 & 3.50 & 5.00 \\
\hline & South & 163 & 4.4571 & .65357 & .05119 & 4.3560 & 4.5581 & 2.00 & 5.00 \\
\hline & Total & 313 & 4.4856 & .58476 & .03305 & 4.4206 & 4.5507 & 2.00 & 5.00 \\
\hline \multirow{4}{*}{ People } & North & 71 & 2.1690 & 61495 & .07298 & 2.0235 & 2.3146 & 1.00 & 5.00 \\
\hline & Central & 79 & 2.1709 & .46607 & .05244 & 2.0665 & 2.2753 & 200 & 4.50 \\
\hline & South & 163 & 2.0123 & 34673 & .02716 & 1.9586 & 2.0659 & 1.00 & 5.00 \\
\hline & Total & 313 & 2.0879 & .45585 & .02577 & 2.0372 & 2.1386 & 1.00 & 5.00 \\
\hline \multirow{4}{*}{ Process } & North & 71 & 3.8310 & 83214 & .09876 & 3.6340 & 4.0279 & 200 & 5.00 \\
\hline & Central & 79 & 4.0190 & 63772 & .07175 & 3.8761 & 4.1618 & 2.50 & 5.00 \\
\hline & South & 163 & 3.7515 & .69026 & .05407 & 3.6448 & 3.8583 & 200 & 5.00 \\
\hline & Total & 313 & 3.8371 & .71877 & .04063 & 3.7571 & 3.9170 & 2.00 & 5.00 \\
\hline
\end{tabular}

Table - 7 Relation between the Customers' Evaluation of the Product, Place, Pricing, Promotion, People and Process $\$$

\begin{tabular}{|c|c|c|c|c|c|c|}
\hline Factors & Sources & $\begin{array}{l}\text { Sum of } \\
\text { Squares }\end{array}$ & df & $\begin{array}{l}\text { Mean } \\
\text { Square }\end{array}$ & $\mathrm{F}$ & Sig. \\
\hline \multirow{3}{*}{ Product } & Between Groups & .657 & 2 & .329 & 2.083 & .126 \\
\hline & Within Groups & 48.913 & 310 & .158 & & \\
\hline & Total & 49.571 & 312 & & & \\
\hline \multirow{3}{*}{ Place } & Between Groups & 28.423 & 2 & 14.212 & 92.204 & .000 \\
\hline & Within Groups & 47.781 & 310 & .154 & & \\
\hline & Total & 76.204 & 312 & & & \\
\hline \multirow{3}{*}{ Pricing } & Between Groups & 2.471 & 2 & 1.236 & 11.034 & .000 \\
\hline & Within Groups & 34.712 & 310 & .112 & & \\
\hline & Total & 37.183 & 312 & & & \\
\hline \multirow{3}{*}{ Promotion } & Between Groups & 3.051 & 2 & 1.525 & 4.563 & .011 \\
\hline & Within Groups & 103.634 & 310 & .334 & & \\
\hline & Total & 106.685 & 312 & & & \\
\hline \multirow{3}{*}{ People } & Between Groups & 1.944 & 2 & .972 & 4.790 & .009 \\
\hline & Within Groups & 62.890 & 310 & 203 & & \\
\hline & Total & 64.834 & 312 & & & \\
\hline \multirow{3}{*}{ Process } & Between Groups & 3.810 & 2 & 1.905 & 3.752 & .025 \\
\hline & Within Groups & 157.380 & 310 & .508 & & \\
\hline & Total & 161.190 & 312 & & & \\
\hline
\end{tabular}

From the above desk it could be observed that Spot, Costs, Advertising, Folks, as well as Process are actually significant in the three areas of North, Central and South. This causes mean sensible evaluation and it is discovered that the groups location of the item in north zone discovered the maximum $($ mean $=4.1901)$ and gotten optimum in appreciation of prices of the Women SHGs items in central region (method= 3.8897) and also obtained max in appreciation of advertising in core zone (way= 4.6456) and also optimal people in central region $(w a y=2.1709)$ and procedure in Central area $($ mean $=4.0190)$.

Therefore, the analyst wrapped up that among the three marketing areas of north, central as well as southern, Place, Costs, Advertising, People, and Refine realized max connection.

Searchings for 
5.2.23. Strategies of attention used to enhance the investment of Women SHGs items: 241( 62.9\%) participants abstain from any kind of type of interest to their item along with 142 ( $37.1 \%$ ) members are in fact making use of different kinds of interest for improving the sale of their item. Consequently, the expert finished that most of the instance attendees are actually giving without any promotion to their products.

5.2.24. Taking advantage of publicity to strengthen the purchase of Women SHGs items:

$247(67.1 \%)$ attendees provide attention to their products with little note, $28(7.3 \%)$ participants use interest to their item by means of flush panel, 6( $1.6 \%)$ respondents offer promo to their item through free gifts, $81(21.1 \%)$ attendees offer focus to their thing through door-to-door canvassing, 3( $0.8 \%$ ) individuals are actually making use of all form of promo, and also $8(2.1 \%)$ individuals provide focus to their product along with magazine/books. Consequently, the expert completed that a great deal of the members offer promotion to their products with bit notification.

5.7. Customer Assessment of Women Individual Help Teams Products: In customers' standpoint the high quality of items generated by Women SHGs is acceptable and their several SWOT consider all the three marketing and advertising locations, are actually properly reviewed.

5.8. Customers evaluation worrying the Item, Place, Rates, people, Advertising, Process: In consumers' scenery the 3 areas of North, Central and also South Item, Site, Prices, folks, Advertising, Refine are in fact discovered having optimum hookup.

Recommendation

The purchases, revenue and likewise cost savings of the Women Private Help Teams are really certainly not totally related to standard SWOT look at Chennai Urban area. Arising from the clients' perspective, their readiness to get the Women Self Support Team products as well as additionally their arrangement on satisfaction of numerous top-notches depended on via individuals are actually firmly attached. This research precisely showed that despite the fact that the consumers permitted the products created by means of Women Personal Help Group participants in Chennai, the products carried out surely not associate with the consumers at the correct time due to job of SWOT assessment on individuals' edge. On the basis of research study produced the analyst provides the observing tips which will assist the individuals to have accessibility to customers and also know SWOT premium and likewise by means of this enhance the competition of country positioned item in addition to metropolitan area based items in Chennai location.

5.9.4. Determine the 4Ps from time to time: P1: Price: When the individuals have worked out the cost of the items absolutely not just on the basis of consumers' price yet also on the manner of their acceptability of the expense at that point the participants may decide on and also take advantage of the ideal price and produce a questionnaire of their products in the Chennai market. Therefore the individuals require to assist produce periodical examination of the cost for their items.

P2: Region: When the participants hunt for an absolute best region for their item, they may quickly conceal their product for a long period of time stemming from the customers. Unless or there prevails market for their products the participant needs to make a periodical analysis worrying the appropriateness of market spot in Chennai for his items.

P3: Promotion: Most of the group participants in Chennai absolutely never utilized any type of kind of suited purchases marketing approaches for their products. When the members oversight to take the creativity concerning their items to the customers' ideas, the remaining to be 3Ps are actually visiting never ever work well.

P4: Item: When the products are actually doing certainly not invite fulfilment of the demands, demands or perhaps beliefs of individuals for the products are incredibly poor in total requirements with additional extremely reasonable items in the Chennai market. The products undoubtedly lost their general place on the market. Consequently the participants are actually advised to generate periodical analysis pertaining to the value of the product in Chennai market.

5.9.5. Consistently evaluating the furthermore and minus facets of very competitive products:

An honest assessment of plus and likewise minus features of the realistic products provides really crystal clear photo concerning the real product placement in the Chennai market. The attendees ought to develop unique functionality to calculate in addition to take a look at the helpful and additionally unfavorable elements associated with reasonable items in the Chennai market.

5.9.6. Even more attention on product packaging and also display of product appropriate details: The members of Women SHGs are actually unenlightened of packaging as well as also display screen of the products in the Chennai market. A lot of the individuals taken advantage of really poor philistine components to pack their items and also captivating factors in the products are actually completely overlooked. A ton of the items in the market abstain from display screen of important information about the products along with a ton of the clients have actually highlighted this lacuna in the products. Subsequently the individuals are recommended to center a lot more on this worry.

5.9.7. Availability of items with no break: the participants ought to promise regarding the routine of products on the market without any trouble and even damage. The absence of things may be actually a trigger for series of items with also frequenters.

5.9.8. Sustain customers loyalty: preserving customers' devotion on the products is really quite difficult in Chennai market. Given that even leading products are really also discovering it fairly made complex to always keep the individuals' assistance for their items. As a result the participants are in fact recommended to constantly maintain devotion for their items in the elements of "comfortable", "healthy as well as sanitary", "typically well prepared", "no preservative internet information", "fast and very easy acquire access to as well as easy reach" as well as also finally "this is our city's item".

5.9.9. Do not set apart: the participants are recommended "perform certainly not separate" their items along with market stemming from others products in addition to markets. 
Thinking about that when the Women Self Help Crews' products combine along with tackle various other leading or well-known products in Chennai market after that simply the items may be distinctly recognized as a result of the clients as well as additionally markets in Chennai.

5.9.10. Requirement of partnerships and consent: when the members collaborate or even join hand together with some other leading business in Chennai they may find out about the worth and likewise usages of SWOT study and also they might simply make it with in the Chennai market. In addition when the Women Personal Support Teams products get normal permission coming from acknowledged authorizations the clients secure assurance with the items generated through Women Personal Help Staffs in Chennai. 5.9.11. Recognize the worth of SWOT study: the participants should consider the really distinct methods handled through Chinese products in our country. Typically the Mandarin products targeted and brought in the minimal income crew of our people and also market minimal conventional products with low-priced rate. However when the Women Personal Help Staff participants produced higher regular items at affordable price, they situate it definitely complicated to tape-record the open market place for their products. Because they have really knocked off to aid make SWOT assessment along with the individuals are actually urged to tackle SWOT review in addition to enhance their advertising skill-set.

\section{CONCLUSION}

In Chennai accessibility to market and also understanding of market is really still a major obstacle to Women Personal Assistance Team attendees today, as is actually ease of access to SWOT analysis about overall market activities, instruction, coaches, as well as advancement. A lot of the Women Self Assist Team individuals in Chennai do certainly not generate any sort of kind of marketing research prior to becoming part of the market place as well as likewise after entering they definitely never ever produce any kind of type of SWOT testimonial about general advertising elements in the Chennai market. Plus all these hurdles frequently offer extra and one-of-a-kind challenges in taking care of competitors and also clients in their organisation commitments. When the participants proactively eliminate this challenge they might tape simple site available.

\section{REFERENCES}

1. FAO,1988," Women Authorization" In: Development Understanding and also Rural Women, Kanishka Publishers, New Delhi, pp 5-6.

2. Harper (2002), "Marketing of Personal Aid Teams under the SHG Banking company

3. a.Linkage Program in India,": NABARD Publications, Mumbai.

4. Annymous, 1988, Women Empowerment as well as Knowing, Meals in addition to Farming Establishment, Kanishka Publishers, New Delhi, pp 3-4.

5. FAO,1988," Women Empowerment" In: Expansion Learning and Rural Women, Kanishka Publishers, New Delhi, pp 5-6.

6. Uma G,2010, "Standing of Women in Control in Tamil Nadu", The IUP Journal of Authorities and likewise Public Law, Quantity V 2010 Issue March \& June, Pages: 59-84.

7. Tamil Nadu Enterprise for Advancement of women 1td, 2012, Tamil Nadu women.

8. Venture Interference, Women as well as also House Food items Defense, IFAD, 2010,
9. Valentine's's M. Moghadam, 2012, The "Feminization Of Destitution" As well as likewise Women's Constitutional rights Social in addition to Human Scientific Study.

10. Christen, Robert, Rhyne, Elisabeth; Vogel, Robert, McKean, Cressida (1995): "Producing greatest use of the outreach of microenterprise financial": An Analysis of Efficient Microfinance Programmes, Washington, DC, USAID Programme in addition to Methods Analysis File No. 10, 1995.

11. Rosenberg, (1994 ), "Beyond Personal Adequacy Accredited Make Use Of and likewise Microfinance Method", UNITED STATES Company for International Progress, Washington, DC.pp.2.

12. Compunction Pearson, (2000), "Micro credit history need to be actually targeted upright", Business Line, March 9, pp. 14

13. Shasi Rajagopalan, (1999), "Women as well as Micro Money", Individual Support Team Headlines, Vol.II (3-4), pp. twenty.

14. Harper (2002 ), "Marketing of Private Help Staffs under the SHG Banks Linkage Plan in India,": NABARD Publications, Mumbai.

15. Murthy, Rao, (1997), "Dealing With Challenge: Indian NGO and also their Capability Renovation in the 1990s", New Delhi: Friedrich Ebert Browsing.

16. Ganapathy R.( 2006 ), Effective Entrepreneurship Growth Programme, HRD Moments, Vol:8 No:5, May 2006.

17. Sankaran A (2009), Craze as well as likewise Concerns of Non-urban Women Entrepreneurs in India, Southern Business Analyst, July 15, 2009 . 